\title{
Chemical Composition and in Vitro Digestibility of Five Heavily Fertilized Tropical Grasses in Puerto Rico ${ }^{1}$
}

\author{
J. A. Arroyo-Aguilu, S. Tessema, R. E. McDowell, P. J. Van Soest, \\ A. Ramirez and P. F. Randel ${ }^{2}$
}

\begin{abstract}
Samples from five tropical grass species: Guinea (Panicum maximum), Pangola (Digitaria decumbens), Congo (Brachiaria ruziziensis), Merker (Pennisetum purpureum), and Star (Cynodon nlemfuensis), were harvested during nine weeks at ages from 7 to 63 days in southwestern Puerto Rico. The grasses were fertilized at the rate of $4480 \mathrm{~kg} / \mathrm{ha}$ per year with a 15-5-10 fertilizer.

The crude protein content of all grasses exceeded 10 percent up through 28 days of regrowth. Grasses declined in crude protein from a mean of 18.1 percent at 7 days to 5.6 percent at 63 days. A narrower range was observed between grasses from 42 to 63 days.

The five tropical grasses possessed high contents of structural carbohydrates, principally cellulose and lignin, which increased with age, except in Pangola grass. Silica did not change uniformly with age in any of the grasses while hemicellulose was characterized by marked fluctuations.

Digestibility values were lower at all stages of growth than in temperate forages of similar ages. Cellulose was negatively correlated with in vitro digestibility in all grasses except Pangola. Lignin appeared to be the predominant factor in determining digestibility. The relationship of silica to digestibility varied between species, being positive in some (Guinea and Congo) and negative in others (Star, Pangola, and Merker).

The grasses may be ranked as follows with regard to their chemical composition and digestibility: Merker $>$ Congo $>$ Star $>$ Guinea $>$ Pangola. Pangola grass, though lowest in in vitro digestibility, declined least with advancing age, thus maintaining a more constant quality for a longer period of time.

1 Manuscript submitted to Editorial Board October 14, 1974.

${ }^{2}$ Associate Nutritionist, Animal Husbandry Department, Agricultural Experiment Station, University of Puerto Rico, Río Piedras, P.R.; Officer-in-Charge, Holetta Guenet Experiment Station, Ethiopia; Professors of International Animal Science and Animal Nutrition, Department of Animal Science, Cornell University, Ithaca, N.Y.; and Assistant Animal Husbandman and Nutritionist, Agricultural Experiment Substation, University of Puerto Rico, Lajas, P.R., respectively.
\end{abstract}




\section{INTRODUCTION}

There are a number of high yielding tropical grass species as measured by dry matter yields (17). Tropical grasses have been reported as having a lower feeding value (3) due to a rapid decline in crude protein (CP) content and digestibility and an increase in crude fiber and lignin $(L)$ contents with increasing maturity. This may not necessarily be correct if tropical grass selection and proper management based on nutritive values are considered $(1,5,6)$.

More advanced systems of evaluating feed $(5,9)$ are being developed continually and these are being utilized to improve the knowledge of the chemical composition and digestibility of forages. In the Tropics, there is a greater need (12) for fractionating forage dry matter into individual chemical entities and classifying them according to their relative nutritional availability. The purpose of this study was to determine the nutritive value of five tropical grass species at stages of growth that would correspond to recommended grazing time for green chop or for preservation as silage and hay.

\section{PROCEDURE}

This study was conducted at the University of Puerto Rico Agricultural Experiment Substation at Lajas, located on the southwestern coast at $18^{\circ}$ latitude and $67^{\circ}$ longitude.

The area is characterized as semiarid, with an average rainfall of 112 cm. Rainfall is heaviest during August to October and lightest from January to March. The maximum temperature is around $31.1^{\circ} \mathrm{C}$ and the minimum is $18.3^{\circ} \mathrm{C}$, with about $3^{\circ} \mathrm{C}$ change with season.

The soil is classified as Fraternidad clay. It is a very dark grayish brown and friable granular clay in the top $15 \mathrm{~cm}$ but firm and massive when wet. It breaks into a prismatic structure when dry from 15 to $30 \mathrm{~cm}$ down.

The grass species: Guinea (Panicum maximum-P.R.P.I. 3622), Pangola (Digitaria decumbens), Congo (Brachiaria ruziziensis), Merker (Pennisteum purpureum), and Star (Cynodon nlemfuensis), are all used as pasture grasses in Puerto Rico. The Guinea grass variety was selected due to its high dry matter yield as compared to 15 other Panicums (16).

The grasses were grown in pure stands of nonreplicated .4-ha plots. The plots were fertilized at the rate of $4480 \mathrm{~kg} / \mathrm{ha}$ per year with a 15-5-10 fertilizer. Irrigation was applied at approximately 2 -week intervals during the dry season. Prior to the start of the experiment, all plots were cut to a height of $5 \mathrm{~cm}$. Commencing after 7-day regrowth, grass samples were hand-collected from August to November 1970 at 7-day intervals up to 
63 days. Sampling was done by clipping the grass at heights estimated to be those at which animals would select them under grazing conditions.

About $3 \mathrm{~kg}$ of green material were clipped from each plot at each sampling. This sample was air-dried in the shade on a concrete floor for a period of 7 days. It was then ground in a Wiley mill to pass through a 2-and a 1. $\mathrm{mm}$ screen. After being thoroughly mixed, the material was subsampled, bottled in 8-oz plastic jars and sent to Cornell University for chemical analyses.

Dry matter was determined by direct oven-drying of samples at $100^{\circ} \mathrm{C}$ for 5 hours. Crude protein $(\mathrm{N} \times 6.25)$ was determined by macro Kjeldahl digestion and distillation using 4 percent boric acid as the receiving medium $(2,15)$.

Goering and Van Soest's techniques (9) for cell-wall constituents or neutral-detergent fiber (NDF), acid-detergent fiber (ADF), permanganate $\mathrm{L}$, cellulose (C), and silica (Si) were employed. Hemicellulose (H) was determined as the difference between NDF and ADF.

The Tilley and Terry (19) 2-stage in vitro rumen fermentation procedure, as modified by Goering and Van Soest (9), was employed to determine in vitro true digestibility (IVTD). All relationships with IVTD apply to in vitro apparent digestibility (IVAD) (tables 1 and 2), as the latter was calculated as the difference between IVTD and 12.9 (9), an estimate of endogenous and bacterial excretion. The source of rumen liquor was a fistulated cow on an all-forage (orchardgrass and timothy) diet. Incubation was carried out under anaerobic conditions by a continuous flow of $\mathrm{CO}_{2}$ through the flasks.

Standard regression and correlation analyses were utilized as outlined by Steel and Torrie (18).

\section{RESULTS AND DISCUSSION}

\section{AGE AND SPECIES IN CHEMICAL COMPOSITION}

Wide ranges in structural composition were observed among species and plant age (tables 1 and 2). Even at 7 days of age, CP, NDF, L, C, and Si varied 12.2, 18.4, 3.8, 12.6, and 3.0 percentage units among grasses, respectively. At 63 days, these variations were 2.7, 5.7, 2.9, 7.9, and 4.0 percentage units, respectively. Similar results were obtained for most of the same grasses by Coward et al. (5).

The relationship of the various components (correlation coefficients) with age are presented in tables 3 and 4 . As the plants matured, $C$ and $L$ tended to increase in all species, except Pangola grass. Lignin content in Pangola grass was nonsignificantly higher at 28 days than at 63 days.

There was no significant relationship between $\mathbf{H}$ and age in Guinea 
TABLE 1.-Mean chemical composition and in vitro digestibility of five tropical forage grasses

\begin{tabular}{|c|c|c|c|c|c|c|}
\hline Constituent ${ }^{2}$ & Guinea & Pangola & $\begin{array}{l}\text { Species } \\
\text { Congo }\end{array}$ & Merker & Star & Grand Mean \\
\hline \multicolumn{7}{|c|}{ Percent } \\
\hline CP & 8.9 & 9.3 & 8.8 & 12.0 & 9.9 & 9.8 \\
\hline NDE & 65.8 & 69.6 & 64.9 & 59.7 & 68.1 & 65.6 \\
\hline ADF & 45.3 & 43.8 & 36.9 & 37.4 & 40.8 & 40.8 \\
\hline $\mathbf{H}$ & 20.5 & 25.8 & 28.1 & 22.4 & 27.4 & 24.8 \\
\hline $\mathbf{L}$ & 6.5 & 6.3 & 5.4 & 4.4 & 5.5 & 5.6 \\
\hline C & 34.2 & 33.4 & 28.7 & 28.4 & 30.8 & 31.1 \\
\hline $\mathbf{S i}$ & 4.5 & 3.6 & 2.5 & 4.1 & 3.6 & 3.7 \\
\hline IVTD & 71.9 & 68.1 & 75.4 & 78.7 & 71.3 & 73.1 \\
\hline IVAD & 59.0 & 55.2 & 62.5 & 65.8 & 58.4 & 60.2 \\
\hline $\mathrm{L} / \mathrm{C}$ & 18.3 & 18.8 & 18.6 & 14.9 & 17.5 & 17.6 \\
\hline $\mathbf{L} / \mathbf{H}$ & 31.4 & 24.5 & 19.1 & 19.1 & 20.3 & 22.9 \\
\hline $\mathrm{H} / \mathrm{C}$ & 61.1 & 77.3 & 99.2 & 80.3 & 90.1 & 81.6 \\
\hline L/ADF & 13.8 & 14.3 & 14.4 & 11.3 & 13.3 & 13.4 \\
\hline
\end{tabular}

${ }^{1} \mathrm{CP}$, crude protein; NDF, neutral-detergent fiber; ADF, acid-detergent fiber; $\mathrm{H}$, hemicellulose; $\mathrm{L}$, lignin; $\mathrm{C}$, cellulose; $\mathrm{Si}$, silica; IVTD, in vitro true digestibility; IVAD, in vitro apparent digestibility.

TABLE 2.-Mean chemical composition and in vitro digestibility of five tropical forage grasses at nine plant ages

\begin{tabular}{|c|c|c|c|c|c|c|c|c|c|c|}
\hline \multirow{2}{*}{ Constituent' } & \multicolumn{9}{|c|}{ Plant Age } & \multirow{2}{*}{$\begin{array}{l}\text { Grand } \\
\text { Mean }\end{array}$} \\
\hline & 7 & 14 & 21 & 28 & 35 & 42 & 49 & 56 & 63 & \\
\hline & \multicolumn{10}{|c|}{ Percent } \\
\hline CP & 18.1 & 15.1 & 12.1 & 10.7 & 7.8 & 6.9 & 6.0 & 5.7 & 5.6 & 9.8 \\
\hline NDF & 56.1 & 67.6 & 61.2 & 65.3 & 68.1 & 68.9 & 71.1 & 70.3 & 71.8 & 65.6 \\
\hline ADF & 32.0 & 34.6 & 37.6 & 40.7 & 42.7 & 43.7 & 45.0 & 45.1 & 45.8 & 40.8 \\
\hline H & 24.1 & 23.0 & 23.6 & 24.6 & 25.4 & 25.4 & 26.1 & 25.2 & 26.0 & 24.8 \\
\hline $\mathbf{L}$ & 3.4 & 4.1 & 4.4 & 5.6 & 6.9 & 6.4 & 6.6 & 6.9 & 7.4 & 5.6 \\
\hline C & 24.8 & 26.3 & 28.3 & 31.3 & 32.9 & 33.1 & 34.7 & 34.1 & 34.5 & 31.1 \\
\hline Si & 3.4 & 3.5 & 3.6 & 3.6 & 3.8 & 3.8 & 3.5 & 3.9 & 3.9 & 3.7 \\
\hline IVTD & 84.7 & 82.3 & 77.9 & 74.5 & 71.9 & 68.8 & 66.7 & 66.7 & 64.1 & 73.1 \\
\hline IVAD & 71.8 & 69.4 & 65.0 & 61.6 & 59.0 & 55.9 & 53.8 & 53.8 & 51.2 & 60.2 \\
\hline $\mathrm{L} / \mathrm{C}$ & 12.8 & 14.8 & 14.6 & 17.2 & 17.4 & 18.8 & 18.4 & 19.8 & 20.8 & 17.6 \\
\hline L/H & 13.8 & 17.2 & 18.4 & 22.2 & 23.0 & 25.2 & 25.4 & 26.7 & 28.8 & 22.9 \\
\hline $\mathrm{H} / \mathrm{C}$ & 101.0 & 86.6 & 83.6 & 78.6 & 77.6 & 76.8 & 75.4 & 74.4 & 76.2 & 81.6 \\
\hline L/ADF & 9.8 & 11.0 & 11.2 & 13.0 & 13.2 & 14.2 & 13.8 & 15.0 & 15.6 & 13.4 \\
\hline
\end{tabular}

${ }^{1} \mathrm{CP}$, crude protein; NDF, neutral-detergent fiber; ADF, acid-detergent fiber; $\mathrm{H}$, hemicellulose; L, lignin; C, cellulose; Si, silica; IVTD, in vitro true digestibility; IVAD, in vitro apparent digestibility. 
and Pangola grasses (table 3 ). While $\mathrm{H}$ increased significantly $(\mathrm{P}<.01)$ with age in Congo and Merker grasses, it declined with age in Star grass.

Silica was nonsignificantly related with age in Guinea, Pangola, Congo and Merker grasses (table 3). However, Si content increased significantly $(\mathrm{P}<.05)$ in Star grass.

Crude protein content showed the greatest percentage change with age in all five grasses. Although these grasses were fertilized at the same rate, CP content ranged from 24.6 percent (Merker grass) to 12.4 percent (Pangola grass) at the 7-day period. Johnson et al. (10) obtained high values

Table 3.-Simple correlation coefficients between plant age and chemical constituents of five tropical forage grasses

\begin{tabular}{lccccc}
\hline Constituent1 & Guinea & Pangola & Congo & Merker & Star \\
\hline CP & $-.97^{* * 2}$ & $-.91^{* *}$ & $-.87^{* *}$ & $-.93^{* *}$ & $-.90^{* *}$ \\
ADF & $.96^{* *}$ & .30 & $.89^{* *}$ & $.97^{* *}$ & $.85^{* *}$ \\
H & .08 & .43 & $.74^{*}$ & $.80^{* *}$ & -.07 \\
L & $.98^{* *}$ & .10 & $.95^{* *}$ & $.96^{* *}$ & $.89^{* *}$ \\
C & $.93^{* *}$ & .25 & $.88^{* *}$ & $.96^{* *}$ & $.86^{* *}$ \\
Si & -.39 & .51 & -.44 & .59 & $.78^{*}$ \\
IVTD & $-.98^{* *}$ & $-.66^{* 3}$ & $-.92^{* *}$ & $-.99^{* *}$ & $-.89^{* *}$ \\
L/C & $.97^{* *}$ & .04 & $.91^{* *}$ & $.89^{* *}$ & $.88^{* *}$ \\
L/H & $.98^{* *}$ & -.08 & $.87^{* *}$ & $.91^{* *}$ & $.87^{* *}$ \\
H/C & $-.78^{* *}$ & .25 & $-.66^{*}$ & -.58 & $-.87^{* *}$ \\
L/ADF & $.96^{* *}$ & .01 & $.94^{* *}$ & $.90^{* *}$ & $.90^{* *}$ \\
\hline
\end{tabular}

$1 \mathrm{CP}$, crude protein; ADF, acid-detergent fiber; H, hemicellulose; L, lignin; C, cellulose; $\mathrm{Si}$, silica; IVTD, in vitro true digestibility.

3 ** Significant at the 1-percent level.

$3 *$ Significant at the 5-percent level.

for CP in Merker grass only at very immature stages where harvesting is impractical due to low yields. Throughout the 63-day period, all grasses declined in CP from a mean of 18.1 percent at 7 days to 5.6 percent at 63 days (table 2). A narrower range was observed between grasses from 42 to 63 days. Tropical grasses tend to have a relatively high CP content, when young and immature, as compared to many temperate grass species (7). However, the rate of CP decline was much faster than in temperate species. Johnson et al. (10) indicated that, with increasing maturity, CP decline was more rapid in warmer than in colder seasons.

Taking all grasses and ages into consideration (table 4), CP, NDF, $A D F, L$, and $C$ were significantly $(P<.01)$ correlated with age, with negative coefficients for $\mathrm{CP}$ and positive ones for all other parameters. 
Hemicellulose and $\mathrm{Si}$ were not significantly correlated with age. Similar correlations were obtained by Arroyo-Aguilú and Coward-Lord (1) between age and $\mathrm{CP}, \mathrm{NDF}, \mathrm{ADF}, \mathrm{L}$ and $\mathrm{C}$.

\section{FIBROUS FRACTIONS}

The relationships among fibrous fractions in all grasses and between $\mathrm{L}, \mathrm{C}$, and $\mathrm{H}$ in individual grasses are presented in tables 4 and 5 , respectively. In all grasses (table 4), NDF was significantly $(P<.01)$ correlated to $\mathrm{ADF}, \mathrm{H}, \mathrm{L}$ and $\mathrm{C}$ but not to $\mathrm{Si}$. Acid-detergent fiber was significantly correlated to $\mathrm{L}$ and $\mathrm{C}(\mathrm{P}<.01)$ and to $\mathrm{Si}(\mathrm{P}<.05)$ but not to H. Hemicellulose content was significantly $(\mathrm{P}<.01)$ correlated to $\mathrm{Si}$ but not to $\mathrm{L}$ or $\mathbf{C}$.

There was a wider range among species in $\mathrm{H} / \mathrm{C}$ than in the other ratios (table 1). The data in tables 2 and 4 shows that $\mathrm{H} / \mathrm{C}$ decreased significantly $(\mathrm{P}<.01)$ with age in all grasses, as opposed to $\mathrm{L} / \mathrm{C}, \mathrm{L} / \mathrm{H}$, and $\mathrm{L} / \mathrm{ADF}(\mathrm{P}<.01)$. This suggested that $\mathrm{H}$ is attached to $\mathrm{L}$ as demonstrated in $\mathrm{L} / \mathrm{H}$ as maturity advanced (table 2 ).

In Merker grass only, $\mathrm{L}$ and $\mathrm{C}$ were positively and significantly $(\mathrm{P}<$ .01) correlated with $H$ (table 5). Congo grass showed a significant $(P<$ .01) negative relationship between $\mathrm{Si}$ and $\mathrm{H}$, with negative relationships in Guinea, Pangola, and Star grasses and positive in Merker grass. Lignin content was significantly $(P<.01)$ correlated to $C$ in all species except Pangola grass. Lignin was not uniformly associated with $\mathrm{Si}$, ranging from a significant $(\mathrm{P}<.01)$ positive relationship in Star grass to negative relationships in Congo and Guinea grasses. Cellulose was significantly $(\mathrm{P}<$ .01) correlated with $\mathrm{Si}$ in Merker and Star grasses only. Pangola grass was the only grass showing no significance among fibrous fractions.

Increased structural carbohydrates in tropical grasses are generally related to the desiccating environment causing early onset of lignification and to the high environmental temperatures and high transpiration causing thick cell walls necessary for support and rigidity of the tropical species $(7,8)$. However, since the environmental factor would have a uniform effect on all species growing under very similar conditions, it would seem that environment is not the only main effect.

These relationships provided evidence that tropical species possess inherent physiological attributes to deposit various chemical constituents differently in their tissues.

Compared to some temperate grasses (4), tropical grasses had a higher content of structural carbohydrates. These were $L$ and $C$ and suggested a higher effect on digestibility, in contrast to Olubajo et al. (14) where $L$ and $\mathrm{C}$ were not related in tropical grasses. 


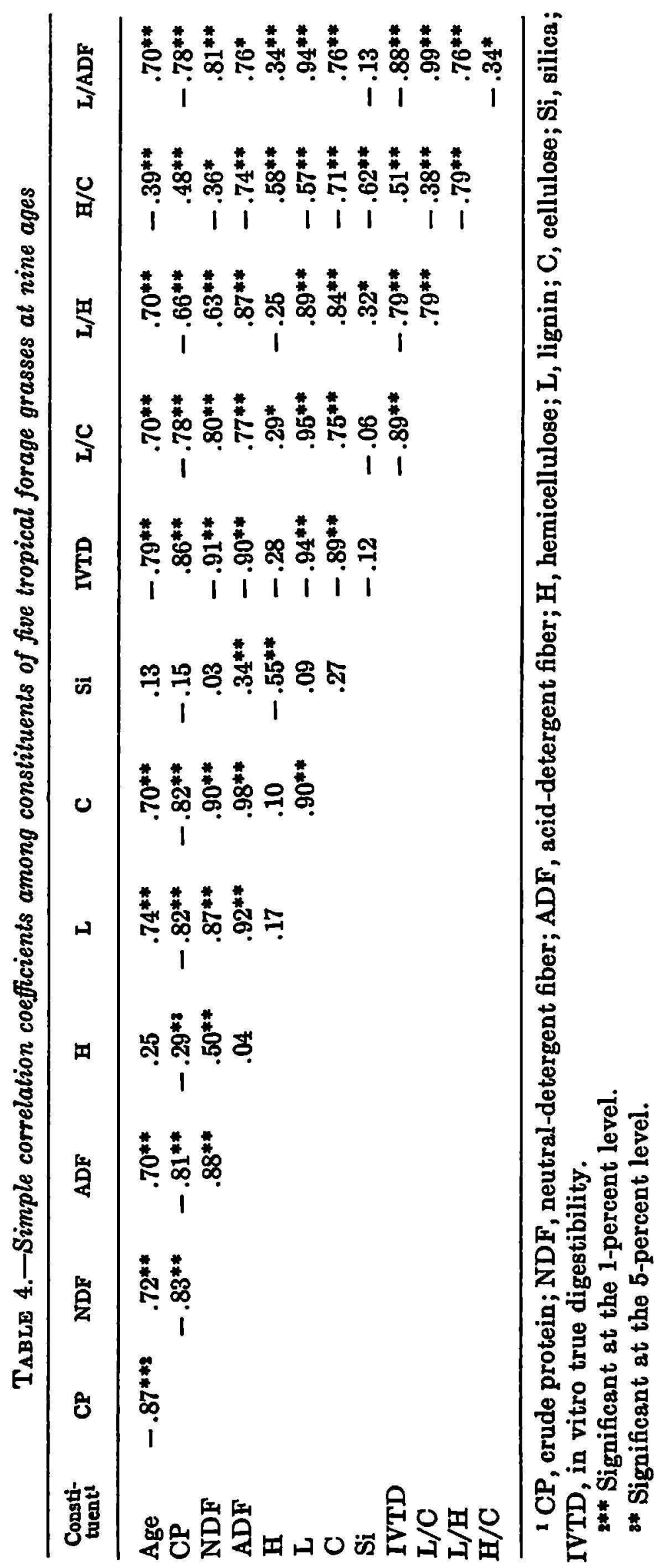


TABLE 5.-Simple correlation coefficients between various constituents of five tropical forage grasses

\begin{tabular}{lccccc}
\hline Variable Correlatedı & Guinea & Pangola & $\begin{array}{l}\text { Species } \\
\text { Congo }\end{array}$ & Merker & \multicolumn{1}{c}{ Star } \\
\hline H with L & .14 & -.00 & .60 & $.78^{* * 2}$ & -.10 \\
H with C & .11 & .48 & .60 & $.82^{* *}$ & .12 \\
H with Si & -.41 & -.46 & $-.83^{* *}$ & .33 & -.22 \\
L with C & $.96^{* *}$ & .39 & $.94^{* *}$ & $.90^{* *}$ & $.96^{* *}$ \\
L with Si & -.51 & .05 & -.32 & .43 & $.78^{* *}$ \\
C with Si & -.53 & -.30 & -.40 & $.66^{* 8}$ & $.77^{* *}$ \\
\hline
\end{tabular}

${ }^{1} \mathrm{H}$, hemicellulose; L, lignin; C, cellulose; $\mathrm{Si}$, silica.

2** Significant at the 1-percent level.

3* Significant at the 5-percent level.

\section{IN VITRO DIGESTIBILITY}

The patterns of decline in the digestibility of tropical grasses are closely associated with the increase in the structural components. These declines were more related to $L$ than to any other component (table 4 ). The negative relationships between $L$ and IVTD were significant in Pangola grass $(\mathrm{P}<.05)$ and in the other four species $(\mathrm{P}<.01)$ (table 6$)$.

There was a significant negative relationship $(P<.01)$ between IVTD and Star grass Si (table 6). However, there was no relationship between $\mathrm{Si}$ and IVTD in Guinea, Pangola, Congo and Merker grasses. As a result,

TBLE 6.-Simple correlation coefficients between in vitro digestibility and chemical constituents of five tropical forage grasses

\begin{tabular}{lccccc}
\hline Constituentsi & Guinea & Pangola & Congo & Merker & Star \\
\hline CP & $.97^{* * 2}$ & $.65^{* 2}$ & $.98^{* *}$ & $.91^{* *}$ & $.99^{* *}$ \\
ADF & $-.97^{* *}$ & $-.69^{*}$ & $-.97^{* *}$ & $-.95^{* *}$ & $-.97^{* *}$ \\
H & -.02 & -.22 & -.56 & $-.83^{* *}$ & -.01 \\
L & $-.97^{* *}$ & $-.71^{*}$ & $-.97^{* *}$ & $-.97^{* *}$ & $-.97^{* *}$ \\
C & $-.94^{* *}$ & -.38 & $-.94^{* *}$ & $-.95^{* *}$ & $-.98^{* *}$ \\
Si & .39 & -.42 & .28 & -.51 & $-.84^{* *}$ \\
L/C & $-.95^{* *}$ & $-.63^{*}$ & $-.92^{* *}$ & $-.91^{* *}$ & $-.95^{* *}$ \\
L/H & $-.98^{* *}$ & -.56 & $-.95^{* *}$ & $-.91^{* *}$ & $-.94^{* *}$ \\
H/C & $.83^{* *}$ & .07 & $.85^{* *}$ & .51 & $.97^{* *}$ \\
L/ADF & $-.94^{* *}$ & -.62 & $-.94^{* *}$ & $-.92^{* *}$ & $-.96^{* *}$ \\
\hline
\end{tabular}

${ }^{1} \mathrm{CP}$, crude protein; ADF, acid-detergent fiber; H, hemicellulose; L, lignin; C, cellulose; Si, silica.

3** Significant at the 1-percent level.

3* Significant at the 5-percent level. 
considering the five grasses at the nine ages, no significant relationship was obtained (table 4). Between Si and IVTD, Van Soest et al. (23) obtained significant $(P<.05)$ differences in Congo, Guinea and Star grasses but none in Merker and Pangola grasses.

Van Soest and Jones (21) reported that Si depressed IVTD in temperate grasses. The relationships found in Star grass were in agreement with their observations. However, Minson (13) concluded that Si was not a factor controlling IVTD in 57 samples of three cultivars of Panicum species.

Cellulose was negatively correlated $(P<.01)$ with IVTD in all grasses except Pangola. Inasmuch as $\mathrm{C}$ is completely digestible by rumen microorganisms, such negative relationships reflected the extent to which its availability is impaired by $L$. A significant $(P<.01)$ negative correlation coefficient was obtained between $\mathrm{C}$ and IVTD in all grasses together (table 4).

The correlation coefficient between $\mathrm{L}$ and $\mathrm{C}$ content in Pangola grass was low (.40) (table 5), but there was a significant $(P<.01)$ negative relationship between IVTD and lignification of the $C$ (table 5). Since $C$ by itself is not related to IVTD of Pangola grass, the C in Pangola grass must be highly lignified, and therefore, unavailable.

Table 6 shows wide differences between species in relationships between IVTD and $\mathrm{H}$. Correlation coefficients ranged from nonsignificant $(r=$ $-.01)$ to significant $(\mathrm{P}<.01, r=-.84)$. While $\mathrm{H}$ was negatively correlated with IVTD in all grasses, $\mathrm{H} / \mathrm{C}$ was positively correlated to IVTD. Apparently greater quantity of $\mathrm{H}$ was associated to higher digestibilities, though $\mathrm{H}$ itself was highly digestible. A similar trend, although in the opposite direction, was observed in the relationship between $\mathrm{C}$ and $\mathrm{H}$ in the grass species (table 3 ).

In vitro true digestibility can also be calculated by means of a summative system, utilizing the $\mathrm{L}$ content of $\operatorname{ADF}(X)$ in the equation: $Y=$ $180.8-96.6 \log X$, where $Y$ is IVTD (20). A comparison of this system with the in vitro system in temperate grasses gave a correlation of .96 (22). Using the summative equation and the in vitro system (table 7), high correlations $(P<.01)$ were obtained in four of these grasses. For Pangola grass, the correlation was lower $(P<.05)$, probably due to the lignification in Pangola grass. Kayongo-Male et al. (11) concluded that the summative equations gave results that were poorly correlated with in vitro digestibility, when applied to tropical forages from Puerto Rico.

Correlation coefficients between the digestibility from the summative equation and other plant constituents are presented in table 8 . In all species, significant $(P<.01)$ negative correlations were obtained between digestibility and $L$ and between digestibility and L/ADF. These relation- 
ships suggested that $\mathrm{L}$ and L/ADF can accurately estimate IVTD of these grasses.

Van Soest and Jones (21) obtained a decline of 3 units of digestibility per unit of $\mathrm{Si}$, indicating that the availability of organic constituents is being limited by the $\mathrm{Si}$. As a result, they added to the summative equation a correction for $\mathrm{Si}$. Silica functions somewhat in the manner of $\mathbf{L}$, rendering

$\mathrm{T}_{\mathrm{ABLE}}$ 7.-Regression equations of form $\mathrm{Y}=\mathrm{a}+\mathrm{bX}$ for estimating percent in vitro true digestibility $(\mathrm{Y})$ from the summative equation digestibility $(\mathrm{X})$ in five tropical forage grasses

\begin{tabular}{|c|c|c|c|c|}
\hline Species & Intercept & $\begin{array}{l}\text { Coefficient of } \\
\text { regression }\end{array}$ & $\begin{array}{l}\text { Coefficient of } \\
\text { correlation }\end{array}$ & $\begin{array}{l}\text { Standard error } \\
\text { of estimate }\end{array}$ \\
\hline & $a$ & $b$ & $r$ & \\
\hline Guinea & -24.84 & 1.21 & $.95^{* * 1}$ & 8.37 \\
\hline Pangola & $-\quad .86$ & .89 & $.68^{* 2}$ & 23.93 \\
\hline Congo & -33.27 & 1.37 & $.96^{* *}$ & 15.47 \\
\hline Merker & -21.02 & 1.15 & $.97^{* *}$ & 9.55 \\
\hline Star & -30.05 & 1.26 & $.98^{* *}$ & 10.02 \\
\hline
\end{tabular}

1** Significant at the 1-percent level.

2* Significant at the 5-percent level.

TABLE 8.-Simple correlation coefficients between estimated true digestibility (summative equation without silica correction) and chemical constituents in five tropical forage grasses

\begin{tabular}{llllll}
\hline Constituent ${ }^{1}$ & Guinea & Pangola & $\begin{array}{l}\text { Species } \\
\text { Congo }\end{array}$ & Merker & Star \\
\hline H & -.21 & -.00 & -.61 & $-.78^{* * 2}$ & -.00 \\
$\mathrm{~L}$ & $-.95^{* *}$ & $-.99^{* *}$ & $-.99^{* *}$ & $-.99^{* *}$ & $-.99^{* *}$ \\
$\mathrm{C}$ & $-.94^{* *}$ & -.32 & $-.94^{* *}$ & $-.87^{* *}$ & $-.98^{* *}$ \\
$\mathrm{Si}$ & .51 & -.05 & .42 & -.36 & $-.74^{* 3}$ \\
$\mathrm{~L} / \mathrm{ADF}$ & $-.99^{* *}$ & $-.98^{* *}$ & $-.99^{* *}$ & $-.99^{* *}$ & $-.99^{* *}$ \\
\hline
\end{tabular}

${ }^{1} \mathrm{H}$, hemicellulose; L, lignin; C, cellulose; Si, silica.

2** Significant at the 1-percent level.

3* Significant at the 5-percent level.

the cell wall more resistant to cellulolytic attack. This possibility was examined by regressing IVTD on summative equation digestibility with $\mathrm{Si}$ correction (table 9). The results agreed with the earlier findings that $\mathrm{Si}$ had variable effects on the digestibility of these species.

In an overall qualitative evaluation of these five species from the standpoint of digestibility and content of digestion inhibitors, these grasses may be ranked as follows: Merker $>$ Congo $>$ Star $>$ Guinea $>$ Pangola. 
Vicente Chandler et al. (24) reported that, when cattle were given free selection, they preferred the forages in the following order of decreasing palatability: Merker $>$ Guinea > Pangola.

Pangola grass differed from the other grasses in many respects. Correlations between age of plant and chemical composition contradicted the general pattern observed in the other species. Pangola grass would have significant advantages over the other species especially in grazing and management in spite of its low digestibility. Its nutritional worth changes little with time. In situations where it is not possible to harvest and process hay in a short period of time to maintain the highest nutritional value, Pangola grass would excel the other species by maintaining a constant value for a longer period of time.

TABLE 9.-Regression equation of form $\mathrm{Y}=\mathrm{a}+\mathrm{bX}$ for cstimating percent in vilro true digestibility $(\mathrm{Y})$ from the summative equation digestibility with silica correction (X) in five tropical forage grasses

\begin{tabular}{lcccc}
\hline Species & Intercept & $\begin{array}{c}\text { Coefficient of } \\
\text { regression }\end{array}$ & $\begin{array}{c}\text { Coefficient of } \\
\text { correlation }\end{array}$ & $\begin{array}{c}\text { Standard error } \\
\text { of estimate }\end{array}$ \\
\hline Guinea & 6 & 6 & 5 & \\
Pangola & -18.73 & 1.26 & $.96^{* * 1}$ & 8.55 \\
Congo & -15.12 & .79 & $.79^{* *}$ & 17.64 \\
Merker & -24.25 & 1.39 & $.88^{* *}$ & 16.91 \\
Star & -5.59 & .99 & $.97^{* *}$ & 7.66 \\
\hline
\end{tabular}

1** Significant at the 1-percent level.

\section{RESUMEN}

Se evaluaron muestras de las siguientes cinco yerbas forrajeras tropicales: Guinea (Panicum maximum), Pangola (Digitaria decumbens), Congo (Brachiaria ruziziensis), Merker (Penniselum purpureum) y Estrella Cynodon nlemfuensis), de 7 a 63 dias de edad, tomadas a intervalos de corte de 7 días, desde agosto hasta noviembre de 1970.

Los yerbas se establecieron en parcelas de .4 Ha. en la Subestación Experimental Agrícola de la Universidad de Puerto Rico en Lajas. Se abonaron a razón de $\mathbf{4 4 8 0}$ $\mathrm{Kg}$./Ha. por año con un abono 15-5-10.

Se efectuaron determinaciones químico-snalíticas de proteína cruda (CP) por el método de la AOAC y de fibra neutrodetergente (NDF), fibra ácidodetergente (ADF), lignina (L), celulosa (C) y sílice (Si) por el método de Goering y Van Soest. La digestibilidad real in vitro (IVTD) se efectuó usando la técnica de Tilley y Terry modificada por Goering y Van Soest. La hemicelulosa (H) se determinó por diferencia entre NDF y ADF. Se utilizaron los métodos estadísticos estándares de regresión y correlación para analizar los datos.

El contenido en CP sobrepasó el 10\% hasta la edad de 28 días. El contenido de CP disminuyó de un promedio de $18.7 \%$ a los 7 días a $5.6 \%$ a los 63 días. Se observó una variación más estrecha en CP de los 42 a los 63 días. Las yerbas también presentaron un contenido más elevado en los hidratos de carbono estructurales, principalmente la 
C y la L. Con la excepción de la yerba Pangola, la C y la L aumentaron con la edad de los forrajes. La Si no cambió uniformemente mientras que la $\mathrm{H}$ se caracterizó por fluctuaciones marcadas según las yerbas envejecian.

La digestibilidad de los forrajes tropicales en todas las etapas de crecimiento fue menor que en los de la zona templada de edades similares. La C se correlacionó negativamente con la IVTD en todas las yerbas, excepto en Pangola. La $L$ fue el factor predominante en la determinación de la IVTD. La relación entre la Si y la digestibilidad varió entre especies, siendo positiva en algunas (Guinea y Congo) y negativa en otras (Estrella, Pangola y Merker).

Las gramineas se pueden clasificar en orden descendente como sigue de acuerdo con su composición química y digestibilidad: Merker $>$ Congo $>$ Estrella $>$ Guinea $>$ Pangola. Aunque la yerba Pangola fue la más baja en digestibilidad in vitro, su valor nutritivo fue el que menos decreció con la edad, manteniendo un valor constante por periodos largos.

\section{LITERATURE CITED}

1. Arroyo-Aguilú, J. A., and Coward-Lord, J., Relationships between and within physical and chemical constituents and in vitro true digestibility in tropical forage grasses, J. Agr. Univ. P.R. 58(4) : 437-47, 1974.

2. Association of Official Analytical Chemists, Official Methods of Analysis, 11th ed., Washington, D.C., 1970.

3. Butterworth, M. H., The digestibility of tropical grasses, Nutr. Abs. Rev. 37 : 349-68, 1967.

4. Colburn, M. W., Evans, J. L., and Ramage, C. H., Apparent and true digestibility of forage nutrients by ruminant animals, J. Dairy Sci. 51 : 1450-7, 1968.

5. Coward-Lord, J., Arroyo-Aguilú, J. A., and García-Molinari, O., Fibrous carbohydrate fractions and in vitro true and apparent digestibility of 10 tropical forage grasses, J. Agr. Univ. P.R. 58(3) : 293-304, 1974.

6.,-- , and - Proximate nutrient composition of 10 tropical forage grasses, J. Agr. Univ. P.R. 58(3): 305-11, 1974.

7. Deinum, B., Van Es, A. J. H., and Van Soest, P. J., Climate, nitrogen and grass, II, The influence of light intensity and nitrogen and in vivo digestibility of grass and the prediction of these effects from some chemical procedures, Neth. J. Agr. Sci. 16: 217-23, 1958.

8. French, M. H., Nutritional value of tropical grass and fodder, Herb. Abs. 27: $1-9,1957$.

9. Goering, H. K., and Van Soest, P. J., Forage fiber analyses (apparatus, reagents, procedures, and some applications), Agr. Handbook 379, USDA, 1970.

10. Johnson, W. L., Guerrero, J., and Pezo, D., Cell-wall constituents and in vitro digestibility of Napier grass (Pennisetum purpureum), J. Anim. Sci. 37 : 1255-61, 1973.

11. Kayongo-Male, H., Thomas, J. W., and Ullrey, D. E., Laboratory evaluation of Puerto Rican grasses, J. Anim. Sci. 35: 231 (Abs.), 1972.

12. McDowell, R. E., Cestero, H., Rivera-Anaya, J. D., Román-García, F., ArroyoAguilú, J. A., Berrocal, C., Soldevila, M., López-Alberty, J. C., and Metz, S. W., Tropical grass pastures with and without supplement for lactating cows in Puerto Rico, Univ. P.R. Agr. Exp. Sta. Bull. (in press).

13. Minson, D. J., Influence of lignin and silicon on a summative system for assessing the organic matter digestibility of Panicum, Aust. J. Agr. Res. 22: 589-98, 1971. 
14. Olubajo, F. O., Van Soest, P. J., and Oyenuga, V. A., Comparison and digestibility of four tropical grasses grown in Nigeria, J. Anim. Sci. 38: 149-53, 1974.

15. Scales, F. M., and Harrison, H. E., Boric acid modification of the Kjeldahl method for crop and soil analyses, J. Ind. Eng. Chem. 12: 350-2, 1920.

16. Sotomayor-Ríos, A., Acosta-Matienzo, A., and Vélez-Fortuño, J., Yield comparison and plant character correlations on 16 Panicum accessions, J. Agr. Univ. P.R. 55(2): 174-83, 1971.

17. - - Juliá, F. J., and Arroyo-Aguilú, J. A., Effects of harvest intervals on the yield and composition of 10 forage grasses, J. Agr. Univ. P.R. 58(4): 448-55, 1974.

18. Steel, R. G. D., and Torrie, J. H., Principles and Procedures of Statistics, McGraw-Hill Book Co., Inc., New York, 1960.

19. Tilley, J.M. A., and Terry, R. A., A two-stage technique for the in vitro digestion of forages, J. Brit. Grassland Soc. 18: 104-11, 1063.

20. Van Soest, P. J., Comparison of two different equations for prediction of digestibility of cell contents, cell-wall constituents, and lignin content of acid detergent fiber, J. Dairy Sci. 48: 815 (Abs.), 1965.

21. - , and Jones, L. H. P., Effect of silica in forages upon digestibility, J. Dairy Sci. $51: 1644-8,1968$.

22. —, Wine, R. H., and Moore, L. A., Estimation of the true digestibility of forages by the in vitro digestion of cell walls, Proc. X Inter. Grassland Cong. 438-41, 1966.

23. —- Arroyo-Aguilú, J. A., and Tessema, S., Relationship between silicon content and in vitro digestibility of tropical grasses, J. Dairy Sci. $57: 621$ (Abs.), 1974.

24. Vicente-Chandler, J., Abruña, F., Caro-Costas, R., Figarella, J., Silva, S., and Pearson, R. W., Intensive grassland management in the humid tropics of Puerto Rico, Agr. Exp. Sta. Univ. P.R. Bull. 233, 1974. 